\title{
Topics
}

Dalit Gafni* and Erez Siniver

\section{Is There a Motherhood Wage Penalty for Highly Skilled Women?}

\begin{abstract}
We use a unique data set of all individuals who graduated from universities in Israel during the period 1995-2008 in order to investigate the widening of the gender wage gap during the years following graduation. It is found that the main explanation is having children, rather than skills or academic background. The results show that each additional child reduces a woman's wage by $6.6 \%$, and increases a man's wage by $3.4 \%$. Furthermore, we examine three channels that may explain the motherhood penalty: periods of non-employment, a shift to the public sector and lower-paying firms and the timing of births. Having children increases a woman's period of non-employment while decreasing a man's, and each month of non-employment due to maternity leave reduces a woman's wage by $1.0 \%$, while non-employment reduces a man's wage by only $0.6 \%$. Mothers tend to shift from the private to the public sector and from higher-paying to lowerpaying firms, which offer a more flexible and more convenient work environment, at the cost of a lower salary. Finally, a delay in having children increases a woman's wage while having little, if any, effect on a man's wage. Furthermore, controlling for this variable reduces the estimated motherhood penalty.
\end{abstract}

Keywords: motherhood wage gap, compensating wage differentials, wage differences

DOI 10.1515/bejeap-2013-0191

\section{Introduction and review of the literature}

There is considerable evidence across countries that each additional child lowers a mother's wage by approximately 5\% (Waldfogel 1995; Harkness and

\footnotetext{
*Corresponding author: Dalit Gafni, School of Economics, College of Management, Rishon Letzion, Israel, E-mail: dalit@gafni.co.il

Erez Siniver, College of Management, Academic Studies, Rishon Letzion, Israel, E-mail: sinivr@colman.ac.il
} 
Waldfogel 1999; Korenman and Neumark 1992; Lundberg and Rose 2000), a phenomenon known as the motherhood wage penalty.

There are a number of explanations generally offered for the motherhood wage penalty: (1) Women withdraw, at least temporarily, from the labor force to have children and therefore over time become increasingly less experienced relative to men (Hill 1979; Waldfogel 1998a; 1998b; Budig and England 2001; Beblo and Wolf 2000; 2002; Jacobsen and Levin 1995; Albrecht et al. 1999). (2) Women shift to less demanding jobs as a result of having children (AmuedoDorantes and Kimmel 2005; Waldfogel 1997; Bratti, Del Bono, and Vuri 2004; Nielsen, Simonsen, and Verner 2004; Simonsen and Skipper 2006; Felfe 2009). (3) Employers prefer not to hire women or they discriminate against them (Correll, Benard, and Paik 2007; Browne and Kennelly 1999). (4) Mothers invest less effort in their work and hence are less productive (Becker 1985; Hersch and Stratton 1997; Phipps, Burton, and Lethbridge 2001 who argue that women spend more time on housework and therefore have less time to invest in their careers). (5) Women who intend to have children may invest less in the accumulation of human capital (Mincer and Polachek 1974; Polachek 1981).

We empirically test for the motherhood wage penalty and some of the proposed explanations using a unique data set of all individuals who graduated from university or college in Israel during the period 1995-2008. This group is particularly interesting since college and university graduates are in general more highly motivated, they tend to be more career oriented and they have higher earning potential. We find that the labor force attachment of skilled Israeli women is comparable to that of Israeli men. Thus, during the first 10 years following graduation from university, both women and men in the sample reported an average of 22 months of absence from work. However, there is a large wage gap between skilled men and skilled women, which grows over time. Thus, the wage of men immediately following graduation is $59 \%$ higher than that of women and 10 years later is $90 \%$ higher. The purpose of this research is to determine how much of the growth in the wage gap can be attributed to the differential effect of having children on women and men.

We are not the first to examine the role of the motherhood wage penalty in explaining the wages of highly skilled women. Anderson, Binder, and Krause (2002) find that mothers who did not complete high school do not earn less than their childless counterparts, but that high school and college graduates earn about 10\% less per child. Wood, Corcoran, and Courant (1993) find a wage gap in favor of males among a sample of graduates from the University of Michigan Law School. Gopta and Smith (2002), using a panel of 0.5\% of the Danish population for the period 1980-1995, find that children do not seem to have a negative effect on their mother's wages when experience is controlled for. 
Gangl and Ziefle (2009), using longitudinal data from the British Household Panel Survey, the German Socio-Economic Panel and the National Longitudinal Survey of Youth, find that if one takes account of the potential selectivity of women's employment after childbirth the wage penalty for a mother is between about $10 \%$ and $18 \%$ per child in fixed-effects regression models. Staff and Mortimer (2012), using the Young Development Study sample, find that the hourly wages of mothers are approximately 3\% lower (per child) than the wages of women without children, even after controlling for human capital variables and time-stable sources of unobserved heterogeneity. Accumulated months not in the labor force and not enrolled in school explain the residual pay gap between mothers and other women.

The benefits and rights of men and women after birth in Israel are similar to those in countries such as Britain, France and Italy, with certain differences in the length of maternity leave and its division between the father and mother. The rights of workers after birth in Israel are better than in the US but not as good as in Denmark. A description of the benefits in Israel and a comparison to those in other countries can be found in Appendix 7.

The sample we use has several advantages. It is composed of actual monthly salary data, thus making it possible to derive actual experience and nonemployment periods, particularly non-employment due to maternity. We separate the experience effect into two components: the difference in the number of months of non-employment and the difference in the premium for non-employment between men and women. In addition, we focus not only on the effect of children on women's labor force behavior and wages but also those of men. The data also include information on the graduates' workplaces, thus making it possible to calculate the average wage for each workplace. Felfe (2012) argues that at least part of the motherhood wage penalty is due to the shift of mothers to more convenient jobs. We do not have a direct measure of the treatment of mothers by each employer and instead use the average wage levels in the workplaces, as well as sector (public vs private) as proxies. The fact that we are using a panel enables us to investigate the dynamics of labor force performance. Thus, we can control for the individual effect and are able to examine the effect of changes in workplace and of delaying birth. Finally, the data set includes a number of additional and relevant variables, such as the score on the psychometric exam (which is roughly equivalent to the SAT and measures an individual's abilities), as well as undergraduate field of study (which is usually more specialized in Israel than in the US) and post-graduate degrees.

Differences in earnings between two groups may be explained by differences in the skills they bring to the labor market. Neal and Johnson (1996) find that after controlling for age and performance on the Armed Forces Qualifying Test 
(AFQT), the black-white earnings differential among young men is only about $7 \%$ and statistically insignificant. Thus, the results indicate that the black-white wage gap primarily reflects a skill gap. Lang and Manove (2011) argue that when controlling for AFQT and education blacks earn noticeably less than whites with the same education and cognitive score, and as a result, at least some of the black-white wage differential reflects differential treatment in the labor market. The contribution of this paper is that we control not only for education, like Gopta and Smith (2002), but also for the skill that women bring to the labor market (as represented by the psychometric exam score), as well as field of study and profession.

\section{Data}

The data include all individuals who graduated with a first degree from universities and colleges in Israel during the period 1995-2008. The data for each individual start from his year of graduation and end in 2008. Thus, for example, an individual who graduated in 1995 will have 14 annual observations while an individual who graduated in 2007 will have only one. The data were gathered from various sources by the Central Bureau of Statistics: the data on the individual's academic education were obtained from the universities and colleges; the data on wages were obtained from the Income Tax Authority; and demographic information was obtained from the Population Registry.

The data include the following for each graduate and for each year following graduation:

1. Wage and employment: average monthly wage, number of months worked, number of workplaces, the sector in which the highest monthly wage was earned and the average wage for all workers at each workplace.

2. Demographic information: gender, country of origin, father's country of origin, age, marital status, occurrence of a birth that year, number of children and place of residence.

3. Education: psychometric exam scores, type and name of the academic institution and field of study, both for a first degree and for advanced degrees.

The research population is limited to graduates who remained in Israel and are salaried employees (i.e. it excludes emigrants and the self-employed) and to individuals with monthly salaries of less than NIS 87,828 (thus truncating the wage distribution to remove the top outlying $0.1 \%$ of earners). All the wage data are in NIS in constant 2008 prices. The data are in the form of a panel, where the 
time variable is the number of years since graduation. There is a total of 1.3 million observations for about 250 thousand individuals, resulting in an average of 5.7 observations per individual (Appendix 1 presents the number of observations for various sub-groups). It should be noted that the data for each individual may or may not be continuous since only years with a positive salary were used. The data include significantly more observations for women than for men since there are more female than male graduates. Appendix 2 presents summary statistics for the main variables in the model. It provides some basic results regarding the differences between men and women: men have a higher initial wage and higher wage growth than women; men and women have a similar pattern of cumulative months of non-employment; women tend towards employment in the public sector and in "low-paying" firms"; and the proportion of women in these workplaces tends to rise over time. The data show that the average number of children increases from around zero in the year of graduation to 2.4 after 13 years, which implies that the sample covers the main childbearing years.

\section{Results}

Figure 1 presents the average wage by number of years since graduation and gender. Men earn a higher monthly wage than women during the entire period.

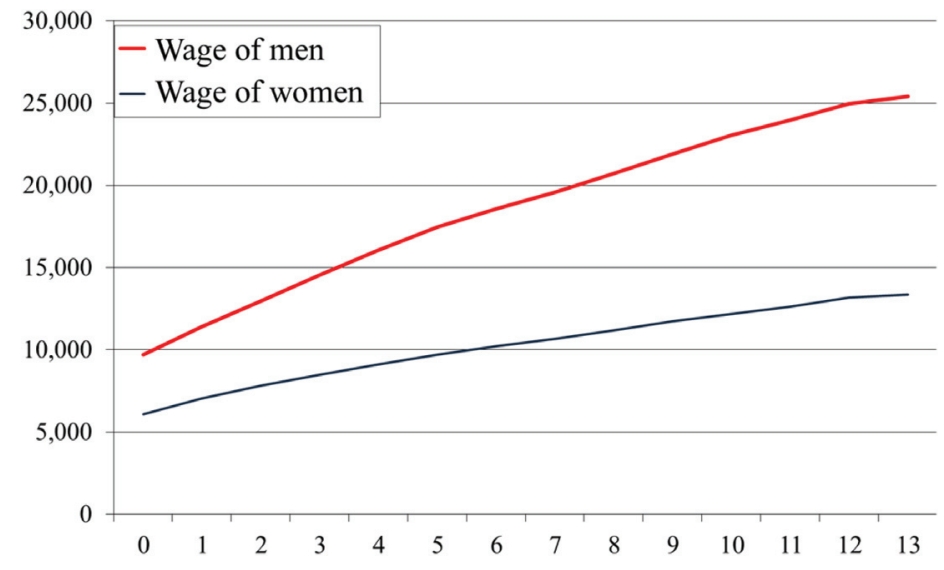

Figure 1: Average monthly wage, by number of years since graduation and gender.

1 A low-paying firm is one that pays its average employee less than the average wage in the same sector (public or private) in a particular year. 
The average wage gap grows from 59\% in the year of graduation to $90 \%$ after 13 years. This translates into an average annual increase of 2.3 percentage points in the wage gap. The increase is not linear: the wage gap increases at an average annual rate of 4 percentage points during the first 5 years after graduation, 1.9 percentage points for the next 5 years and remains unchanged during the last 3 years.

Tables 1-3 present our main estimation results, which were obtained using OLS (Table 1), Fixed Effect (Table 2) and Random Effect (Table 3) to control for unobserved heterogeneity. The dependent variable is log monthly wage ${ }^{2}$ of individual $i$ in year $t$. The explanatory variables include: (1) a dummy for gender and its interaction with accumulated experience (represented by number of years since graduation). Explaining this variable effect, that represents the widening wage gap between men and women, is the focus of this paper. (2) Number of children effect on men and women, which is our explanation to the widening wage gap. (3) Cumulative months of non-employment ${ }^{3}$ (due to maternity leave or any other reason), employment in a low-paying firm or in the public sector, which we claim are three channels of the effect of children on the widening gap. (4) Control variables such as socioeconomic background, education and ability (see comment 4 in Tables $1-3$ ).

The estimated raw wage gap between men and women, as can be seen from column 1 in Table 1 , is $42.1 \%$ on graduation and grows by $2.8 \%$ per year. If background characteristics are controlled for (column 2), the estimated initial gap narrows to only $10.4 \%$, while it has almost no effect on the estimated gap rate of increase. Although adding the number of children only mildly decreases the estimated initial gap, it significantly reduces the annual growth rate of the gap to $1.1 \%$. Adding the effect of cumulative months of non-employment and dummies for employment in a low-paying firm or in the public sector reduces the annual gap growth rate to only $0.3 \%$. Similar results, though not as pronounced, are obtained using the Fixed Effect and Random Effect methods. Thus, for both methods, controlling for individual fixed characteristics (column 1 and 2 in Tables 2 and 3) does not reduce the estimated growth rate of the wage gap over time and even increases it, while the variables related to childbearing eliminate a large portion of it. These results suggest that the increase in the wage gap during the period following graduation is not primarily due to individual characteristics but rather to maternity.

2 Annual salary divided by number of month worked, in 2008 prices.

3 Cumulative number of months with no income since graduation. 


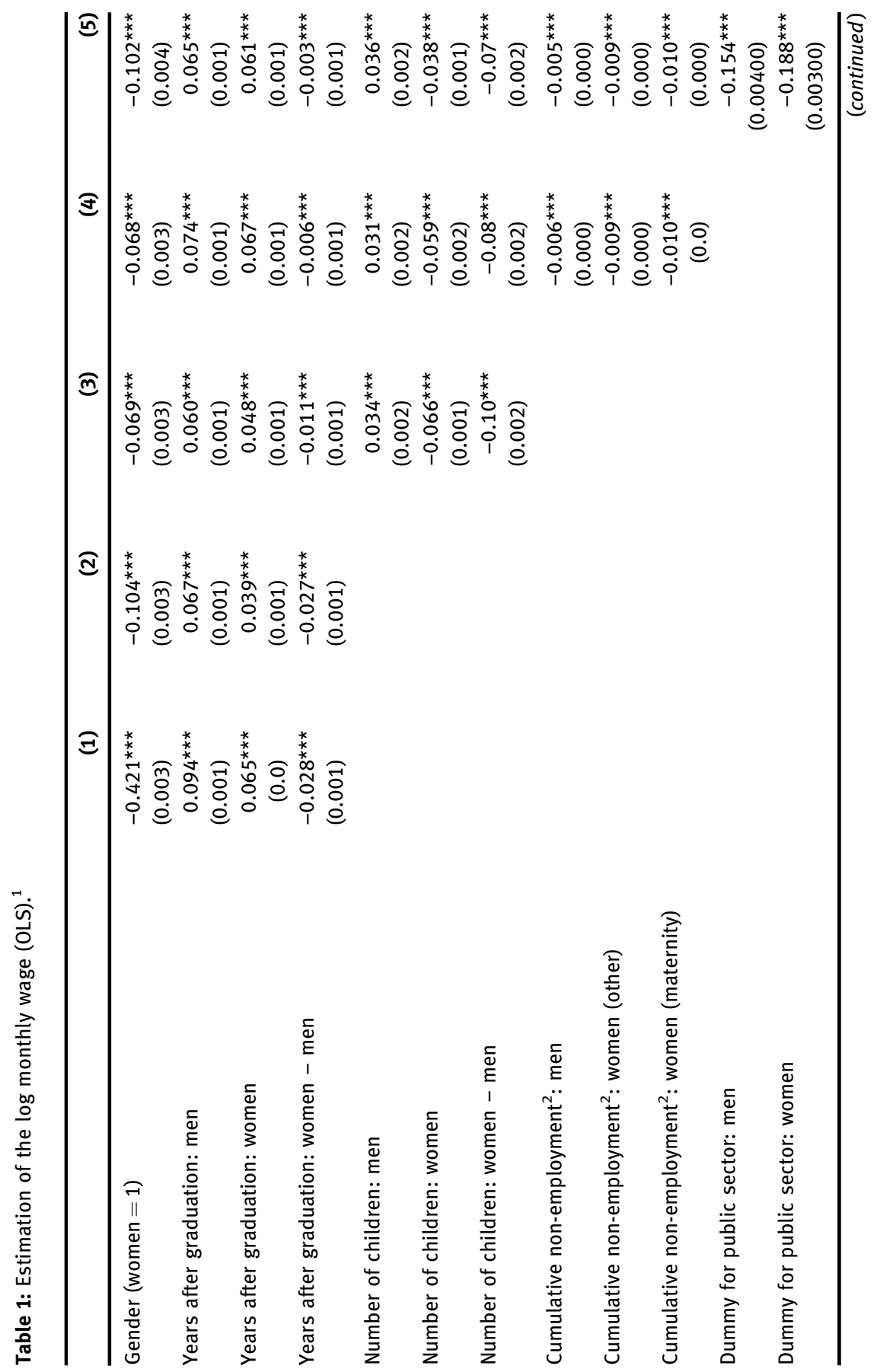




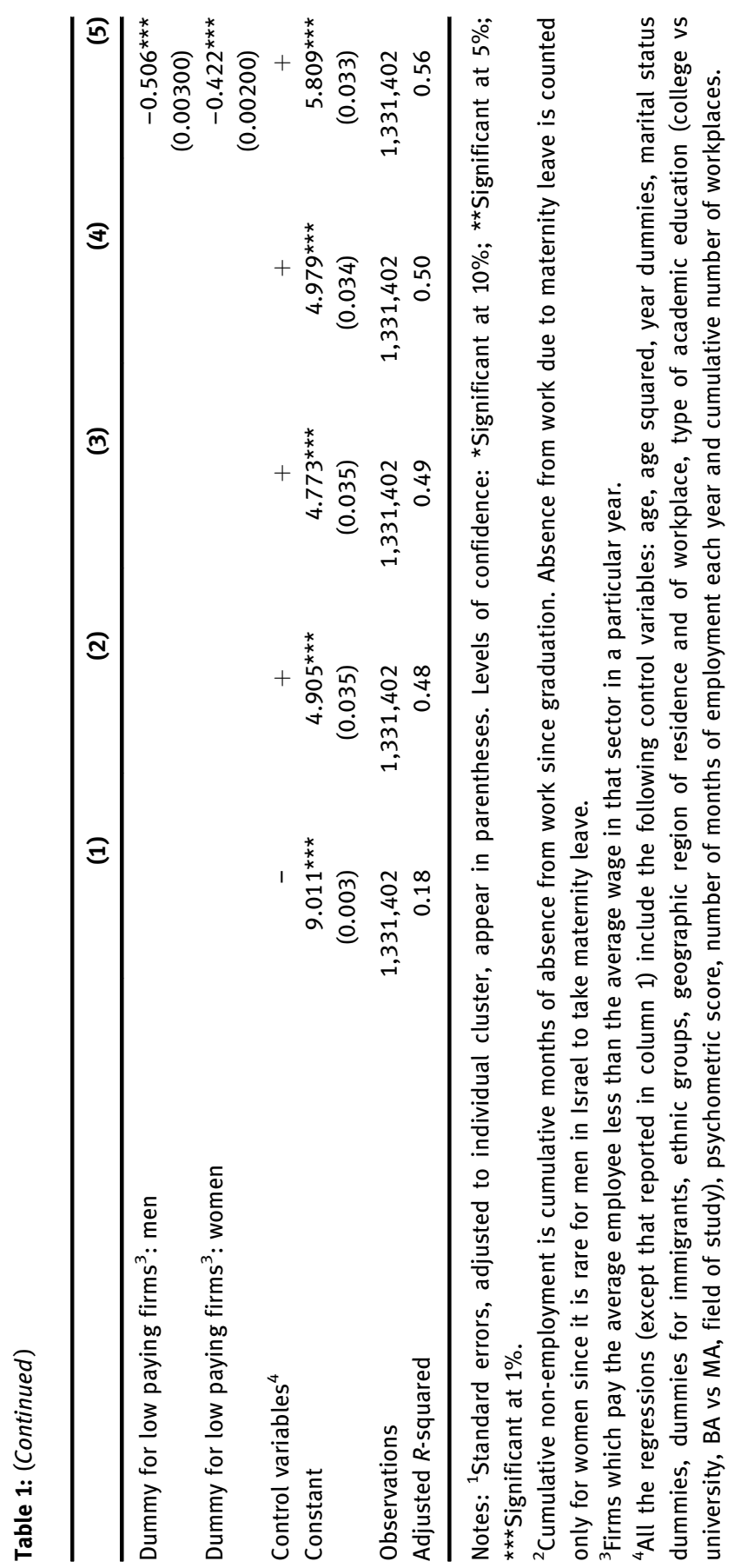




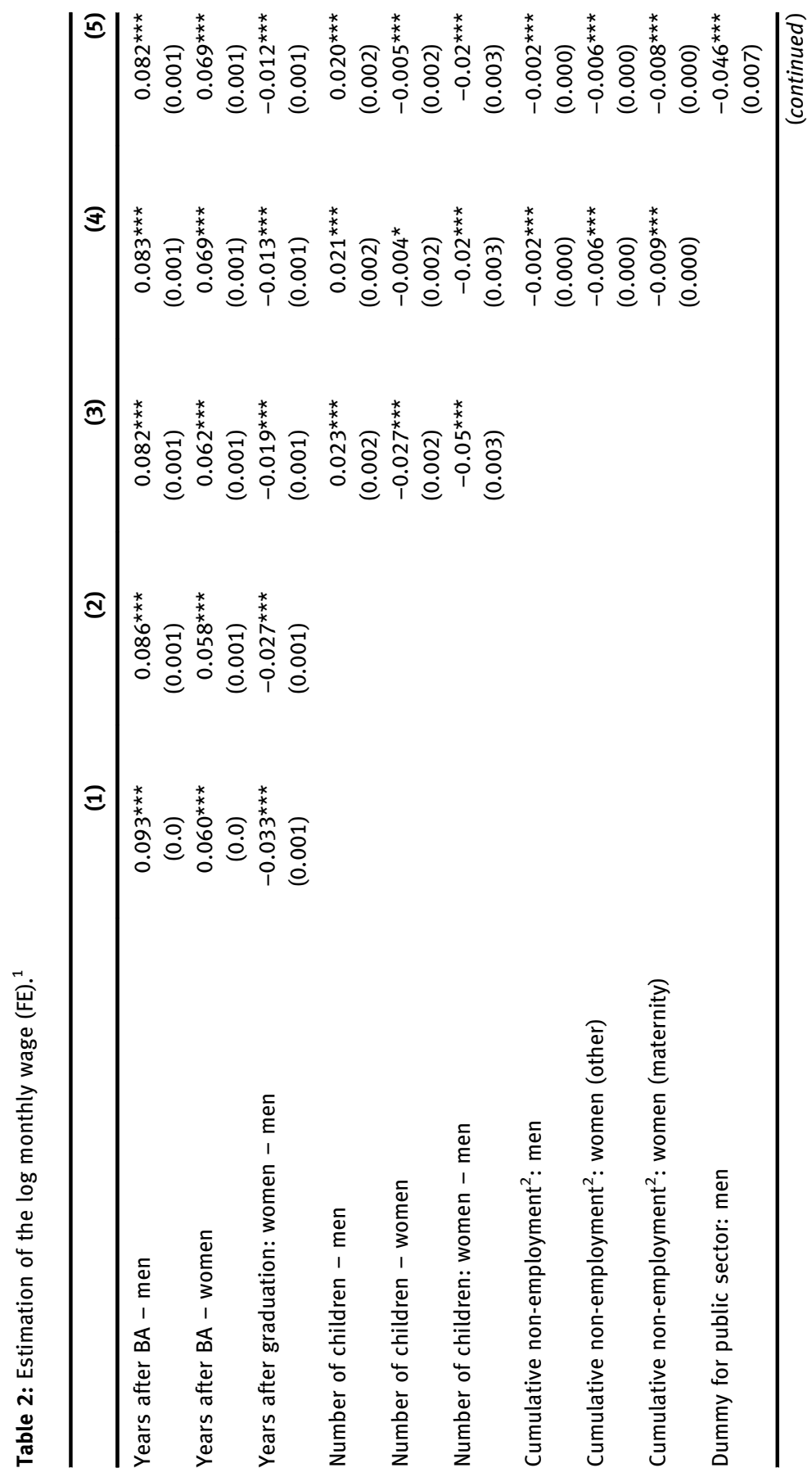




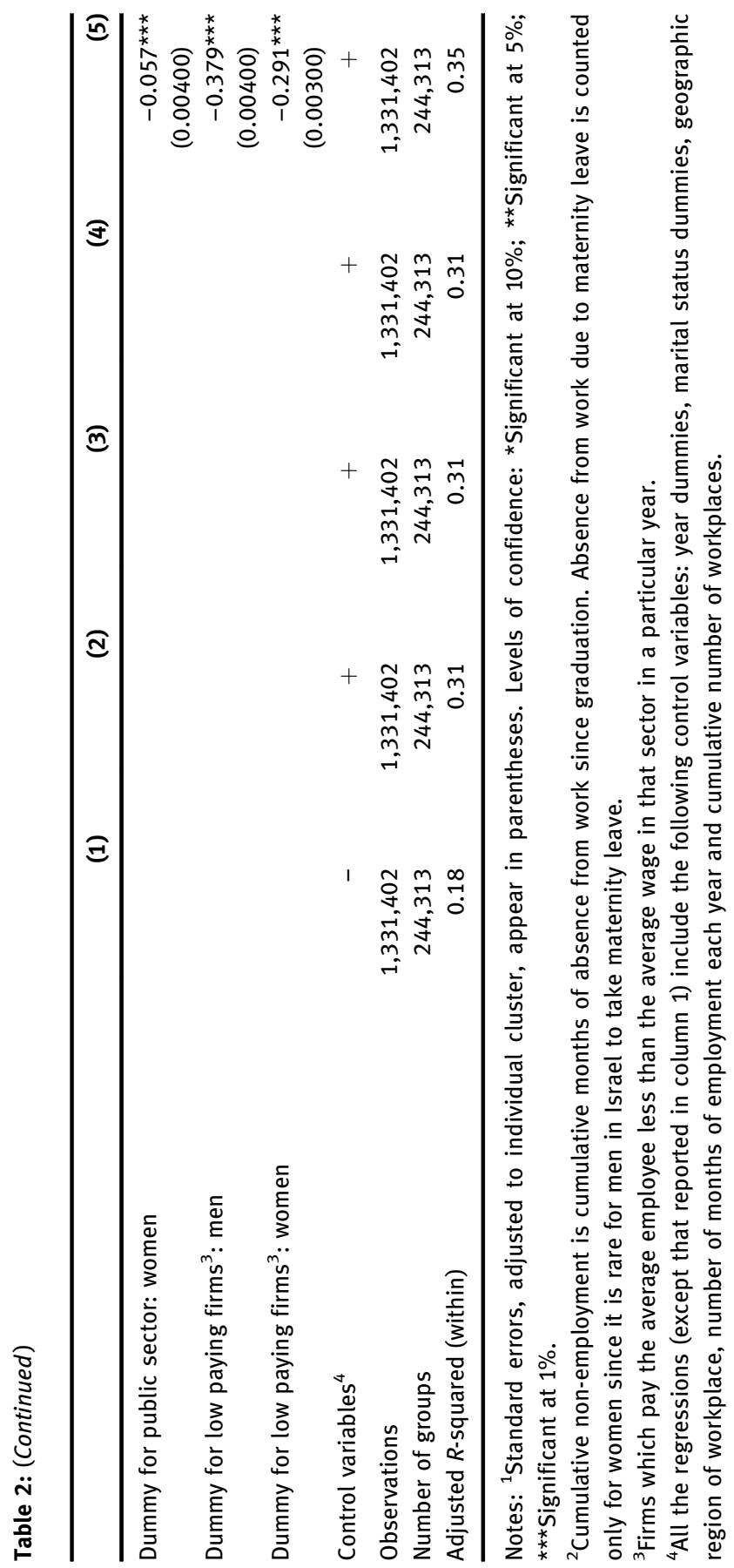




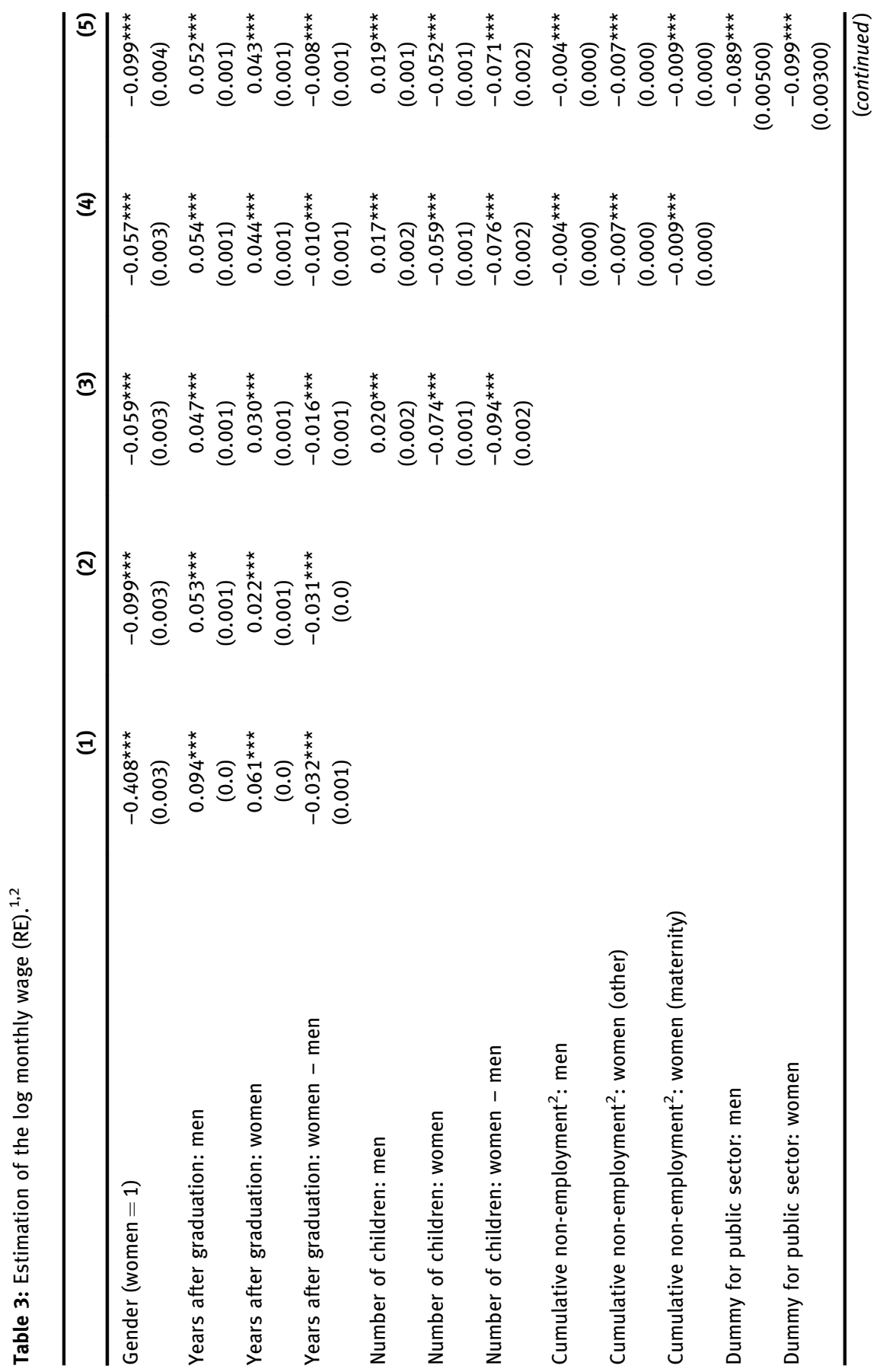




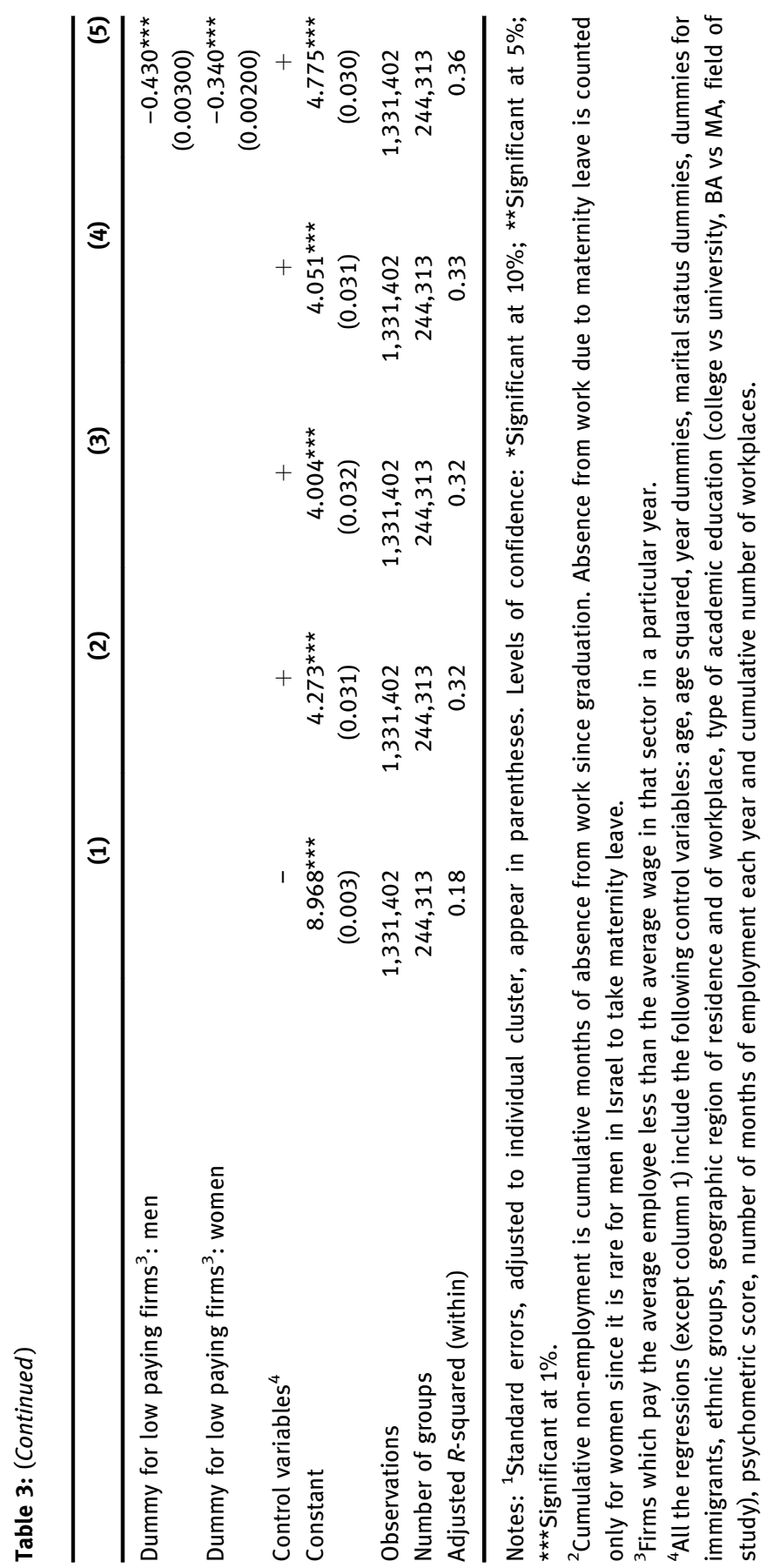




\section{The children effect}

According to the results in column 3 of Table 1, number of children has a negative effect on a woman's monthly wage, such that every additional child reduces her wage by $6.6 \%$. In contrast, the effect is positive for a man, such that each child raises his monthly wage by $3.4 \%$. Thus, each additional child widens the wage gap by $10 \%$. The Fixed Effect and Random Effect estimates are similar though of a smaller magnitude (with the gap increasing by 5.0 and $9.4 \%$, respectively, for each child), indicating that only a small part of the children effect is due to individual characteristics. Adding the cumulative non-employment variables (column 4) decreases the value of these parameters somewhat, indicating that some of the children effect is due to the lag in the accumulation of experience among women relative to men. Adding the type of workplace (column 5) has only a small effect on the estimated children effect.

Appendix 3 presents the results for the same regressions as those in Tables 1-3, except that the children effect is differentiated by birth order. Thus, the first three children have a similar effect on the wage gap (about $10 \%$ ), though for the first child the effect is due to the increase in men's wages while for the second and third the effect is mostly due to a decrease in women's wages. The birth of a fourth or fifth child has less of an effect since the wages of men start to decrease as well. ${ }^{4}$

\section{The work experience effect}

Previous studies have shown that the accumulation of work experience is one of the main factors explaining the increase in wages over time. The most common claim is that women are absent from the labor market for longer periods as a result of giving birth and childrearing and therefore accumulate less work experience than men. Figure 2(a) and 2(b) present the cumulative months of absence from work over time by gender. The raw data presented in Figure 2(a) show that on average men and women are absent from work for similar periods. However, limiting the data to parents who gave birth during the sample period (Figure 2(b)) shows that cumulative absence from work grows at a slower rate for men than for women only after 6 years since graduation.

4 The number of observations is lower in this table since we limit the sample to 5 children or less. 


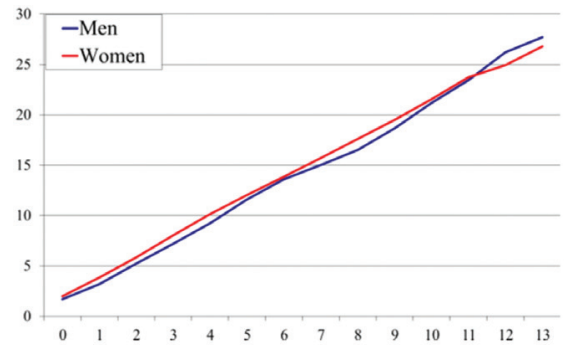

(a)

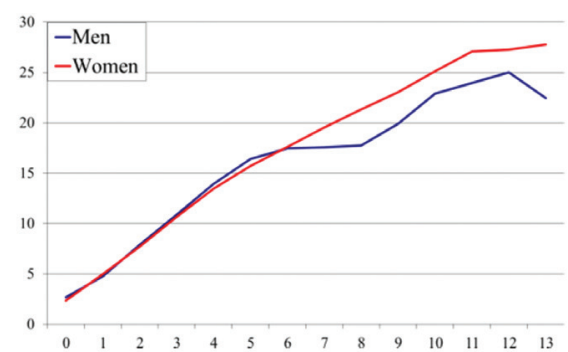

(b)

Figure 2: Cumulative months of non-employment, by years since graduation and gender. (a) All (b) "new families".

Note: The sample is limited to those who had no children on graduation and at least three children by the end of the sample period (i.e. 2008).

Appendix 4 presents the estimated children effect on the cumulative number of non-employment months. The results show that though women have, on average, lower cumulative months of non-employment, having children decreases cumulative non-employment for men and increases it for women, such that every child increases the gap in non-employment by 1.6 months (OLS) in favor of men (and by 3.5 months and 2.75 months for FE and RE, respectively). Tables 1-3 present the penalty for non-employment: according to the OLS estimates in column 4, each month of maternity leave decreases the wage of a woman by $1.0 \%$, while absence for any other reason decreases a woman's wage by $0.9 \%$ and that of a man by only $0.6 \%$. The fixed effect and random effect models present an even higher relative penalty for maternity leave.

Experience appears to have a double negative effect on a woman's wage: women accumulate more absence from work than men and they pay a larger premium for it. Nevertheless, this channel cannot entirely explain the widening of the wage gap and the motherhood penalty, since both are smaller yet significant in column 4 of Tables 1-3.

\section{The workplace effect}

In addition to reduced attachment to the labor force, a second explanation of the motherhood penalty is a shift to a more flexible though less well-paying workplace. Since women tend to take on the role of childrearing, it may be that they shift their focus from work to motherhood. This might be accomplished by 
reducing effort in the workplace, thus slowing promotion, or by reducing the number of hours worked or even by changing to a different kind of workplace. Since we do not possess data on effort and number of hours worked, we focus on the switch to a different workplace. We define two kinds of workplaces that we assume are more flexible but less well-paying:

1. Public sector - in Israel, as in most Western countries, jobs in the public sector offer more flexibility and a less stressful work environment but pay lower wages, relative to the private sector. Thus, a shift to the public sector could potentially explain the motherhood penalty.

2. Lower-paying firms - a different approach to classifying workplaces is according to the average wage they pay, assuming that some of the variance in the average wage across firms is due to differences in the effort required of workers and the flexibility they enjoy. More specifically, we assume that firms that pay less than the average wage, ${ }^{5}$ will compensate their workers by requiring less effort or giving them more flexibility (while holding all other factors constant). Thus, a shift to a lower-paying firm could also explain the motherhood penalty.

\section{A shift from the private to the public sector}

There is a large wage gap between the public and private sectors, particularly in the case of women. As can be seen in Table 1 (column 5), the OLS estimates of the public sector penalty are $15.4 \%$ for men and $18.8 \%$ for women. The fixed and random effect estimates are smaller but still statistically and economically significant.

Figure 3 presents the percentage of employees in the public sector over time and by gender. Thus, $28 \%$ of women work in the public sector following graduation, which increases to $46 \%$ after 13 years, while only $14 \%$ of men work in the public sector following graduation, a level which remains more or less constant over time. Therefore, the gender wage gap can be explained by the greater tendency of women to work in the public sector.

Appendix 5 presents logit estimation results for the probability of working in the public sector. According to column 1, having children increases a woman's probability of being employed in the public sector, but does not affect that of a

5 Relative to the average wage in that sector (i.e. public or private). 


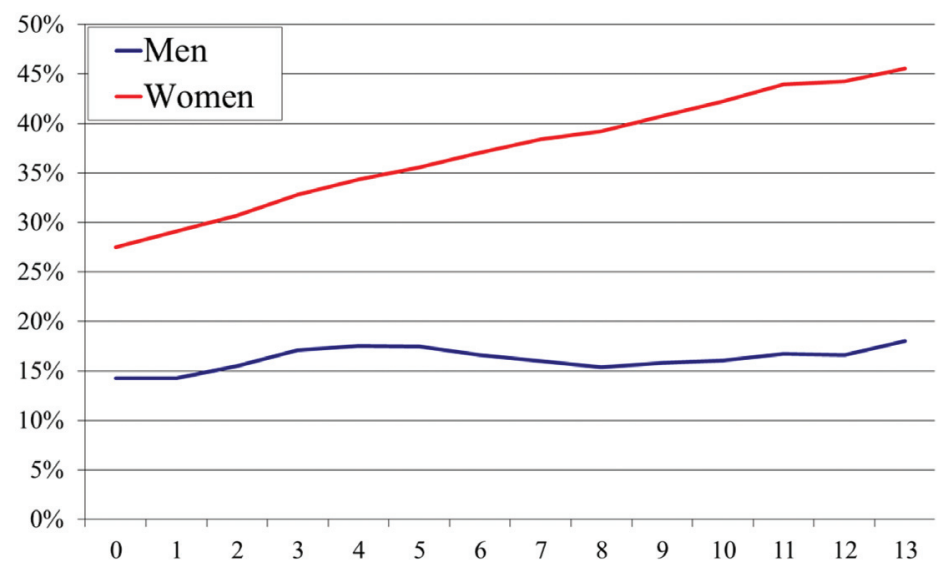

Figure 3: Percentage of workers in the public sector, by years since graduation and gender.

man. Column 2 presents similar estimations for a sub-sample consisting of those who worked in the private sector 3 years after graduation. These results can be interpreted as the probability of moving from the private to the public sector, and indeed they show that having children increases the tendency of women to move to the public sector, while decreasing that of men.

\section{A shift to lower-paying firms}

We define a lower-paying firm as one that pays an average salary which is below the average for all firms in the sector (public or private) in a particular year. This definition allows us to measure the shift from high-paying to low-paying firms, which may explain the widening of the wage gap over time. Table 1 shows that men earn $50 \%$ less in a low-paying firm while women earn $42 \%$ less. The fixed effect estimate is $38 \%$ for men and $29 \%$ for women, which tends to confirm that this effect is meaningful and not only by construction.

Figure 4 presents the proportion of workers in low-paying firms by years since graduation and gender. It shows that some of the workers who start their career in a low-paying firm gradually move to a high-paying firm. This shift toward high-paying firms is stronger for men than women ( $9 \%$ of women and $15 \%$ of men).

Appendix 6 presents the estimated probability of working in a low-paying firm. According to column 1, having children increases the probability of 


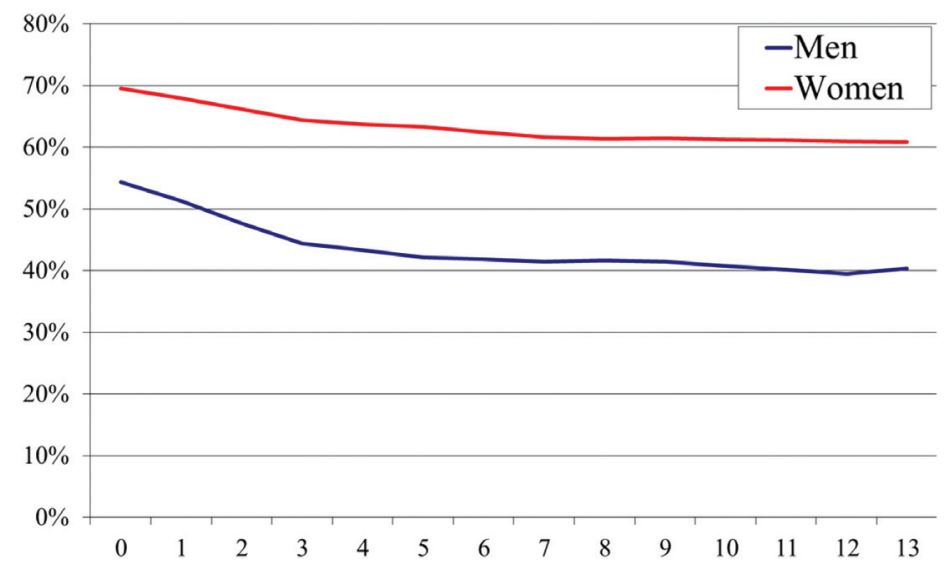

Figure 4: Percentage of workers in a low-paying firm, by years since graduation and gender.

working in a low-paying firm for both men and women, although the coefficient for women is significantly higher. Similar results are presented in column 2, where the sample is limited to those who worked in a high-paying firm 3 years after graduation.

In sum, having children leads women to shift from the private sector to the public sector and from high-paying to low-paying firms. Both result in a decrease in wages, which can be attributed to the motherhood penalty. Nevertheless, adding these variables to the regression (see column 5 in Tables 1-3) changes the estimated children effect only marginally, if at all.

\section{Summary and conclusion}

The key findings of this paper can be summarized as follows:

(1) Men earned a higher monthly wage than women during the entire sample period. The average gender wage gap grew over time from 59\% in the year following graduation to $90 \%$ after 13 years.

(2) After controlling for individual characteristics, men earn 10.6\% more than women on graduation, and the wage gap increases by $2.8 \%$ for each additional year in the labor force (OLS estimates). Accounting for individual unobserved time-invariant heterogeneity (FE and RE) has little effect on the growth of the gap over time. However, when the number of children 
is introduced the estimated wage gap grows by only $1.1 \%$ annually. Adding the effect of cumulative months of non-employment and dummies for employment in a low-paying firm and in the public sector (proxies for jobs that are better suited to parents) reduces the growth in the gap to only $0.3 \%$ annually. These results suggest that the increase in the wage gap over time is primarily due to maternity. Every additional child reduces a woman's wage by $6.6 \%$ and increases that of a man by $3.4 \%$, amounting to $10 \%$ per child $(5.0 \%$ and $9.4 \%$ in the fixed effect and the random effect models, respectively).

(3) Having children increases women's detachment from the labor force (as measured by months of non-employment) while increasing men's attachment to the labor force. Women pay a much higher premium for leaving the labor force than men. Thus, each month of non-employment due to maternity leave reduces a woman's wage by $1.0 \%$ and non-employment due to any other reason reduces it by $0.9 \%$, while a man's wage is reduced by only $0.6 \%$. According to the fixed effect estimate, the difference in the non-employment premium is even higher, such that the maternity premium is $0.9 \%$ while the premium for men's non-employment is only $0.2 \%$.

(4) Once they have children, women tend to switch to a more flexible workplace, which often pays a lower wage. Thus, $25 \%$ of women work in the public sector on graduation, which rises to $45 \%$ after 13 years. Children increase a woman's probability of moving to the public sector, and increase a man's probability of leaving it. In addition, women tend much more than men to move to lower-paying firms after having children.

(5) Even after controlling for time-invariant individual characteristics, career choice, non-employment and a shift to the public sector or a lower-paying job, the children effect is not fully explained. There are apparently additional factors that determine the children effect, such as a shift to part-time work or to a less demanding job in the workplace. However, we were unable to control for these factors due to the lack of data on hours worked and jobs. 


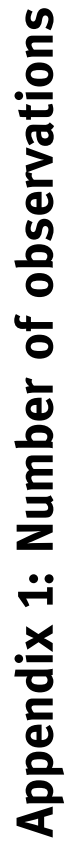

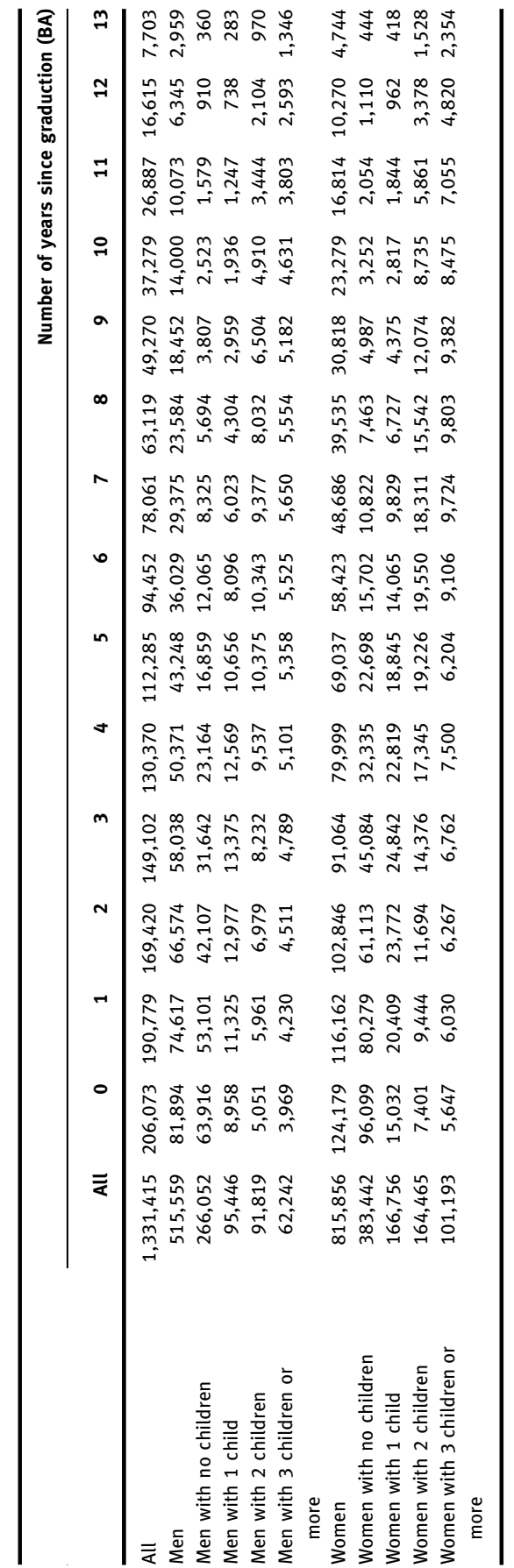




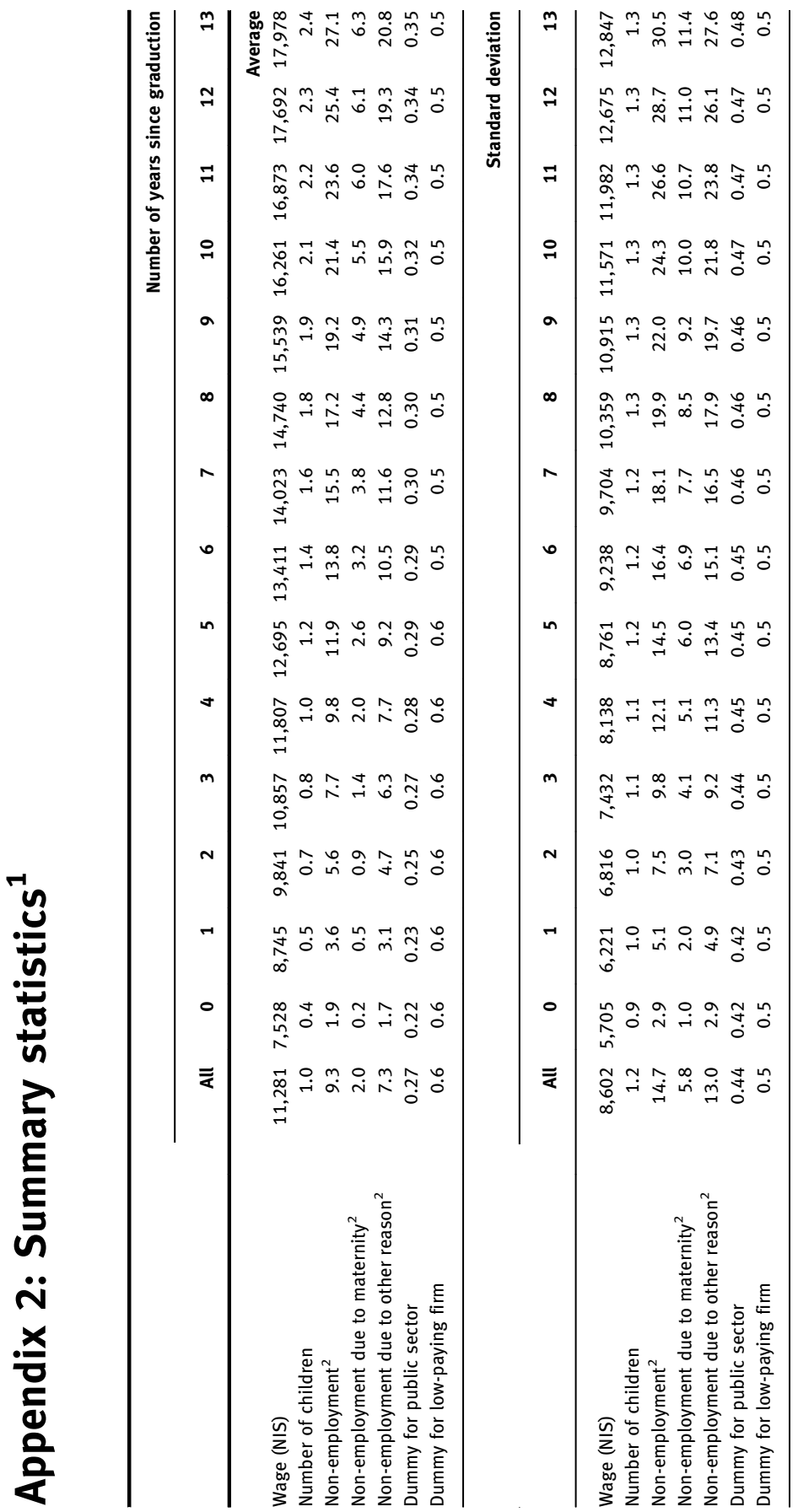




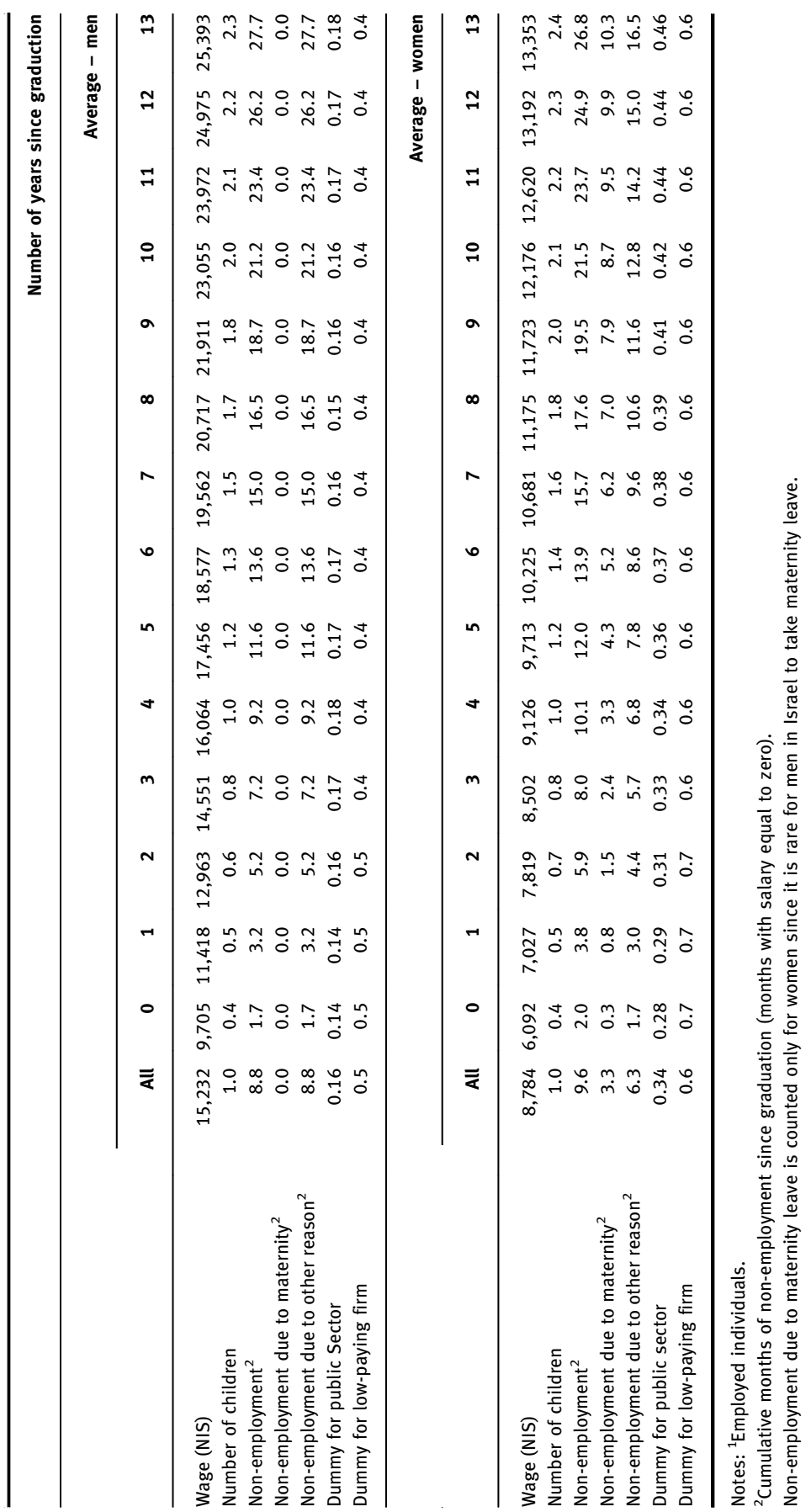




\section{Appendix 3: Estimation of log monthly wage with differentiation of the children effect by birth order $^{1,2}$}

\begin{tabular}{|c|c|c|c|}
\hline & OLS & Fixed effect & Random effect \\
\hline & (1) & (2) & (3) \\
\hline \multirow[t]{2}{*}{ One child: women } & $-0.016^{\star \star \star}$ & $0.016^{\star \star \star}$ & $-0.035^{\star \star \star}$ \\
\hline & $(0.003)$ & $(0.003)$ & $(0.002)$ \\
\hline \multirow[t]{2}{*}{ Two children: women } & $-0.101^{\star \star \star}$ & $-0.016^{\star \star \star}$ & $-0.120^{\star \star \star}$ \\
\hline & $(0.004)$ & $(0.004)$ & $(0.003)$ \\
\hline \multirow[t]{2}{*}{ Three children: women } & $-0.189^{\star \star \star}$ & $-0.087^{\star \star \star}$ & $-0.219^{\star \star \star}$ \\
\hline & $(0.005)$ & $(0.006)$ & $(0.004)$ \\
\hline \multirow[t]{2}{*}{ Four children: women } & $-0.249^{\star \star \star}$ & $-0.161^{\star \star \star}$ & $-0.315^{\star \star \star}$ \\
\hline & $(0.009)$ & $(0.009)$ & $(0.007)$ \\
\hline \multirow[t]{2}{*}{ Five children: women } & $-0.344^{\star \star \star}$ & $-0.267^{\star \star \star}$ & $-0.433^{\star * *}$ \\
\hline & $(0.016)$ & $(0.015)$ & $(0.013)$ \\
\hline \multirow[t]{2}{*}{ One child: men } & $0.098^{\star \star \star}$ & $0.065^{\star \star \star}$ & $0.058^{\star \star \star}$ \\
\hline & $(0.004)$ & $(0.003)$ & $(0.003)$ \\
\hline \multirow[t]{2}{*}{ Two children: men } & $0.140^{\star \star \star}$ & $0.084^{\star \star \star}$ & $0.075^{\star \star \star}$ \\
\hline & $(0.005)$ & $(0.005)$ & $(0.004)$ \\
\hline \multirow[t]{2}{*}{ Three children: men } & $0.151^{\star \star \star}$ & $0.056^{\star \star \star}$ & $0.070^{\star \star \star}$ \\
\hline & $(0.006)$ & $(0.007)$ & $(0.005)$ \\
\hline \multirow[t]{2}{*}{ Four children: men } & $0.119^{\star \star \star}$ & $0.023^{\star \star}$ & $0.053^{\star \star \star}$ \\
\hline & $(0.010)$ & $(0.012)$ & $(0.008)$ \\
\hline \multirow[t]{2}{*}{ Five children: men } & $0.087^{\star \star \star}$ & $-0.035^{\star}$ & 0.023 \\
\hline & $(0.017)$ & $(0.019)$ & $(0.014)$ \\
\hline \multirow[t]{2}{*}{ Constant } & $4.824^{\star \star \star}$ & & $4.031 * \star \star$ \\
\hline & $(0.035)$ & & $(0.032)$ \\
\hline Observations & $1,325,836$ & $1,325,836$ & $1,325,836$ \\
\hline Number of groups & & 243,787 & 243,787 \\
\hline Adjusted $R$-squared & 0.49 & 0.31 & 0.33 \\
\hline
\end{tabular}

Notes: ${ }^{1}$ Standard errors adjusted to individual cluster appear in parentheses. Levels of confidence: ${ }^{\star}$ Significant at $10 \%$; ${ }^{\star \star}$ Significant at $5 \%$; ${ }^{\star \star \star}$ Significant at $1 \%$.

${ }^{2}$ The regressions are the same as those in column 5 in Tables 1-3 and include the same control variables. 


\section{Appendix 4: Estimation of cumulative non-employment (in months) ${ }^{1,2}$}

\begin{tabular}{lccc}
\hline & OLS & FE & RE \\
\cline { 2 - 4 } & $(1)$ & $(2)$ & $(3)$ \\
\hline Gender (women =1) & $-0.922^{\star \star \star}$ & & $-2.385^{\star \star \star}$ \\
Years after graduation: men & $(0.049)$ & & $(0.054)$ \\
& $2.479^{\star \star \star}$ & $1.269^{\star \star \star}$ & $2.018^{\star \star \star}$ \\
Years after graduation: women & $(0.022)$ & $(0.017)$ & $(0.017)$ \\
& $2.144^{\star \star \star}$ & $1.114^{\star \star \star}$ & $1.885^{\star \star \star}$ \\
Years after graduation: women - men & $(0.016)$ & $(0.014)$ & $(0.014)$ \\
& $-0.33^{\star \star \star}$ & $-0.15^{\star \star \star}$ & $-0.13^{\star \star \star}$ \\
Number of children: men & $(0.022)$ & $(0.017)$ & $(0.016)$ \\
Number of children: women & $-0.902^{\star \star \star}$ & $-1.564^{\star \star \star}$ & $-1.325^{\star \star \star}$ \\
Number of children: women - men & $(0.042)$ & $(0.049)$ & $(0.040)$ \\
& $0.740^{\star \star \star}$ & $1.981^{\star \star \star}$ & $1.429^{\star \star \star}$ \\
Observations & $(0.034)$ & $(0.038)$ & $(0.033)$ \\
Adjusted $R$-squared & $1.64^{\star \star \star}$ & $3.54^{\star \star \star}$ & $2.75^{\star \star \star}$ \\
\hline
\end{tabular}

Notes: ${ }^{1}$ Standard errors adjusted to individual cluster appear in parentheses. Levels of confidence: *Significant at $10 \%$; **Significant at $5 \%$; *** Significant at $1 \%$.

${ }^{2}$ The regressions include the same control variables as in Tables 1-3. 


\section{Appendix 5: Estimation of the probability of working in the public sector (logit) ${ }^{1,2,3}$}

Working in the public
sector

(1)

(2)

Gender $($ women $=1)$

$0.183^{\star * *}$

$-0.300^{\star \star \star}$

(0.016)

(0.053)

Years after graduation: men

$-0.027^{\star \star \star}$

$0.073^{\star \star *}$

(0.003)

$(0.008)$

Years after graduation: women

$-0.010^{\star \star \star}$

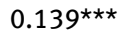

$(0.003)$

Years after graduation: women - men

$0.017^{\star \star \star}$

$0.065^{\star \star \star}$

(0.003)

(0.008)

Number of children: men

$-0.009$

$-0.047^{\star \star \star}$

(0.010)

(0.018)

Number of children: women

$0.207^{\star \star \star}$

$0.147^{\star \star \star}$

Number of children: women - men

$0.215^{\star \star \star}$

$0.194^{\star \star \star}$

$(0.011)$

$(0.020)$

Observations

$1,331,415$

450,168

Adjusted $R$-squared

0.36

0.26

Notes: ${ }^{1}$ Standard errors adjusted to individual cluster appear in parentheses. Levels of confidence: ${ }^{*}$ Significant at $10 \%$; ${ }^{\star \star}$ Significant at $5 \%$; ${ }^{\star \star \star}$ Significant at $1 \%$.

${ }^{2}$ The regressions include the same control variables as in Tables 1-3.

${ }^{3}$ The dependent variable is a dummy for working in the public sector. The sample in column 2 is restricted to only those who worked in the private sector 3 years after graduation. Thus, the estimation represents the probability of moving from the private sector to the public sector. 


\section{Appendix 6: Estimation of the probability of working in a low-paying firm (logit) $1,2,3$}

\begin{tabular}{lcc}
\hline & $\begin{array}{r}\text { Working in a low paying } \\
\text { firm }\end{array}$ & $\begin{array}{r}\text { Moving to a low paying } \\
\text { firm }\end{array}$ \\
\cline { 2 - 3 } & $(1)$ & $(2)$ \\
\hline Gender (women $=1$ ) & $0.080^{\star \star \star}$ & $0.211^{\star \star \star}$ \\
Years after graduation: men & $(0.011)$ & $(0.028)$ \\
Years after graduation: women & $-0.087^{\star \star \star}$ & $-0.109^{\star \star \star}$ \\
Years after graduation: women - men & $(0.002)$ & $(0.005)$ \\
& $-0.080^{\star \star \star}$ & $-0.124^{\star \star \star}$ \\
Number of children: men & $(0.003)$ & $(0.007)$ \\
Number of children: women & $0.007^{\star \star \star}$ & $-0.015^{\star \star \star}$ \\
Number of children: women - men & $(0.003)$ & $(0.008)$ \\
& $0.062^{\star \star \star}$ & $0.028^{\star \star \star}$ \\
Observations & $(0.007)$ & $(0.010)$ \\
Adjusted $R$-squared & $0.209^{\star \star \star}$ & $0.160^{\star \star \star}$ \\
\hline
\end{tabular}

Notes: ${ }^{1}$ Standard errors adjusted to individual cluster appear in parentheses. Levels of confidence: *Significant at $10 \%$; ${ }^{*}$ Significant at $5 \%$; ${ }^{* \star \star}$ Significant at $1 \%$.

${ }^{2}$ The regressions include the same control variables as in Tables 1-3.

${ }^{3}$ The dependent variable is a dummy for working in a low-paying firm. The sample in column 2 is restricted to only those working in a high-paying firm 3 years after graduation. Thus, the estimation represents the probability of moving from a high-paying to a low-paying firm.

\section{Appendix 7: Maternity benefits in Israel and selected countries}

Maternity benefits and the subsidization of daycare in Israel

\section{The wife}

A woman who has worked for at least 1 year for her employer is eligible for a 26week maternity leave. During that period, she receives payments from the 
National Insurance Institute for a period of 14 weeks. The payments are equal to the woman's average salary during the 3 months prior to the birth. The payment is conditional on the average wage not exceeding four times the average salary in the economy.

During the maternity leave, the social welfare rights of the woman that are based on time worked (convalescence pay, sick leave and severance pay) continue to accumulate. If the employer was making payments to the woman's provident fund and/or study fund, he must continue to do so during her maternity leave.

It is not permitted to fire a woman during her maternity leave and for 60 days afterward. A woman who had a multiple birth is eligible for an additional 3 weeks of payments from National Insurance for each additional newborn.

A woman who works fulltime is eligible for 1 hour of nursing time each day. The employer determines the "time of nursing". The eligibility for this right lasts for 4 months starting from the end of the maternity leave. This hour is not deducted from the woman's salary.

\section{The husband}

Men have the right to share maternity leave with their wives. From six weeks after the birth, the man can switch with his wife for the rest of the maternity leave.

The husband is eligible for a maximum of 14 weeks of maternity leave and receives payment from National Insurance for eight of them. The payment from National Insurance is proportional to his salary, such that the family income is maintained.

\section{Subsidy of daycare}

Until 2011, the government did not subsidize daycare. In Israel, education is free from age 5 according to the Law for Free Compulsory Education. In other words, until 2011, the family paid for daycare until that age. Since 2012, the government extended the Law to start from the age of 3. In other words, the government subsidizes daycare for children aged 3 and 4. Since our database includes adults that graduated up until 2008, the extension of the Law ages 3-4 is not relevant to this study.

The following table presents a comparison of maternity benefits in selected countries: 


\begin{tabular}{lrr}
\hline Country & Length of maternity leave (weeks) & Percentage of wages paid \\
\hline Israel & 14 & 100 \\
Germany & 12 & 0 \\
Switzerland & 14 & 100 \\
Denmark & 14 & 80 \\
Sweden & 52 & 100 \\
Italy & 60 & 80 \\
United Kingdom & 20 & have paid maternity leave \\
United States & 52 & 80 \\
& 12 & No national program but some states \\
Ukraine & & 100 \\
Austria & 18 & 100 \\
Spain & 16 & 100 \\
Japan & 16 & 67 \\
\hline
\end{tabular}

\section{References}

Albrecht, J. W., P. Edin, M. Sundstrom, and S. B. Vorman. 1999. "Career Interruptions and Subsequent Wages: A Reexamination Using Swedish Data." Journal of Human Resources 34 (2):294-311.

Amuedo-Dorantes, C., and J. Kimmel. 2005. "The Motherhood Wage Gap for Women in the United States: The Importance of College and Fertility Delay." Review of Economics of the Household 3:17-48.

Anderson, J. D., M. Binder, and K. Krause. 2002. "The Motherhood Wage Penalty: Which Mothers Pay It and Why?" The American Economic Review 92 (2):354-8.

Beblo, M., and E. Wolf. 2000. "How Much Does a Year Off Cost? Estimating the Wage Effects of Employment Breaks and Part-Time Periods," DP 00-69, ZEW.

Beblo, M., and E. Wolf. 2002. "Wage Penalties for Career Interruptions," DP 02-45 ZEW.

Becker, G.1985. "Human Capital, Effort, and the Sexual Division of Labor.”Journal of Labor Economics 3 (1):S34-S58 pt.2.

Bratti, M., E. Del Bono, and D. Vuri. 2004. “New Mothers' Labour Force Participation in Italy: The Role of Job Characteristics,"IZA DP. No.1111.

Browne, I., and I. Kennelly. 1999. "Stereotypes and Realities: Images of Black Women in the Labor Market." In Latinas and African American Women at Work: Race, Gender, and Economic Inequality, edited by I. Browne, 302-26. New York: Russell Sage Foundation.

Budig, M. J., and P. England. 2001. "The Wage Penalty for Motherhood." American Sociological Review 66:204-25.

Correll, S. J., S. Benard, and I. Paik. 2007. "Getting a Job: Is There a Motherhood Penalty." American Journal of Sociology 5:1297-338.

Felfe, C.2009. “The Willingness to Pay for Job Amenities: Evidence from Mothers' Return to Work,"CESifo Working Paper No. 2743. 
Felfe, C.2012. “The Motherhood Wage Gap: What About Job Amenities?” Labour Economics 19 (1):59-67.

Gangl, M., and A. Ziefle. 2009. “Motherhood, Labor Force Behavior, and Women's Careers: An Empirical Assessment of the Wage Penalty for Motherhood in Britain, Germany, and the United States." Demography 46 (2):341-69.

Gopta, N. D., and N. Smith. 2002. "Children and Career Interruptions: The Family Gap in Denmark." Economica 69 (276):609-29.

Harkness, S., and J. Waldfogel. 1999. "The Family Gap: Evidence from Seven Industrialized Countries," CASE paper no.29 Centre for Analysis of Social Exclusion, London.

Hersch, J., and L. S. Stratton. 1997. "Housework, Fixed Effects, and Wages of Married Workers." The Journal of Human Resources 32 (2):285-307.

Hill, M.1979. "The Wage Effect of Marital Status and Children.”Journal of Human Resources 14:579-94.

Jacobsen, J., and L. Levin. 1995. "The Effects of Intermittent Labor Force Attachment on Women's Earnings.” Monthly Labor Review 118:14-19.

Korenman, S., and D. Neumark. 1992. "Marriage, Motherhood, and Wages." Journal of Human Resources 27 (2):233-55.

Lang, K., and M. Manove. 2011. "Education and Labor Market Discrimination.” American Economic Review 101 (4):1467-96.

Lundberg, S., and E. Rose. 2000. "Parenthood and the Earnings of Married Men and Women." Labour Economics 7 (6):689-710.

Mincer, J., and S. Polachek. 1974. "Family Investments in Human Capital: Earnings of Women." The Journal of Political Economy 82:76-108.

Neal, D. A., and W. R. Johnson. 1996. "The Role of Pre-Market Factors in Black-White Wage Differences." Journal of Political Economy 104 (5):869-95.

Nielsen, H. S., M. Simonsen, and M. Verner. 2004. "Does the Gap in Family-Friendly Policies Drive the Family Gap?" Scandinavian Journal of Economics 106:721-44.

Phipps, S., P. Burton, and L. Lethbridge. 2001. "In and Out Of Labour Market: Long-Term Income Consequences of Child-Related Interruptions to Women's Paid Work." Canadian Journal of Economics 34 (2):411-29.

Polachek, S.1981. "Occupational Self-Selection: A Human Capital Approach to Sex Differences in Occupational Structure." The Review of Economics and Statistics 63:60-9.

Simonsen, M., and L. Skipper. 2006. "The Costs of Motherhood: An Analysis Using Matching Estimators." Journal of Applied Econometrics 21:919-34.

Staff, J., and J. T. Mortimer. 2012. "Explaining the Motherhood Wage Penalty During the Early Occupational Career.” Demography 49 (1):1-21.

Waldfogel, J.1995. “The Price of Motherhood: Family Status and Women's Pay in a Young British Cohort." Oxford Economics Papers 47:584-610.

Waldfogel, J.1997. "The Effect of Children on Women's Wages." American Sociological Review 62:209-17.

Waldfogel, J.1998a. "The Family Gap for Young Women in the United States and Britain: Can Maternity Leave Make a Difference." Journal of Labor Economics 16 (3):505-45.

Waldfogel, J.1998b. “Understanding the Family Gap in Pay for Women with Children." Journal of Economic Perspective 12 (1):137-56.

Wood, R. G., M. E. Corcoran, and P. N. Courant. 1993. "Pay Differences Among the Highly Paid: The Male-Female Earnings Gap in Lawyers' Salaries.” Journal of Labor Economics 11

(3):417-41. 